\title{
Front Matter: Volume 10515
}

, "Front Matter: Volume 10515," Proc. SPIE 10515, Vertical External Cavity Surface Emitting Lasers (VECSELs) VIII, 1051501 (6 April 2018); doi: 10.1117/12.2322764

SPIE. Event: SPIE LASE, 2018, San Francisco, California, United States 


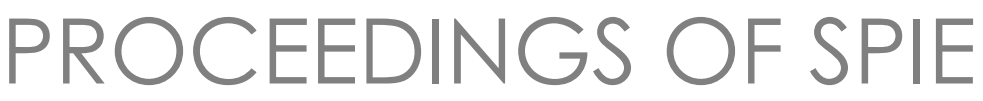

\title{
Vertical External Cavity Surface Emitting Lasers (VECSELS) VIII
}

\author{
Juan L. Chilla \\ Editor
}

\section{9-30 January 2018}

San Francisco, California, United States

Sponsored by

SPIE

Cosponsored by

Coherent, Inc. (United States)

Published by

SPIE 
The papers in this volume were part of the technical conference cited on the cover and title page. Papers were selected and subject to review by the editors and conference program committee. Some conference presentations may not be available for publication. Additional papers and presentation recordings may be available online in the SPIE Digital Library at SPIEDigitalLibrary.org.

The papers reflect the work and thoughts of the authors and are published herein as submitted. The publisher is not responsible for the validity of the information or for any outcomes resulting from reliance thereon.

Please use the following format to cite material from these proceedings:

Author(s), "Title of Paper," in Vertical External Cavity Surface Emitting Lasers (VECSELS) VIII, edited by Juan L. Chilla, Proceedings of SPIE Vol. 10515 (SPIE, Bellingham, WA, 2018) Seven-digit Article CID Number.

ISSN: 0277-786X

ISSN: 1996-756X (electronic)

ISBN: 9781510615151

ISBN: 9781510615168 (electronic)

Published by

SPIE

P.O. Box 10, Bellingham, Washington 98227-0010 USA

Telephone +1 3606763290 (Pacific Time) · Fax +1 3606471445

SPIE.org

Copyright @ 2018, Society of Photo-Optical Instrumentation Engineers.

Copying of material in this book for internal or personal use, or for the internal or personal use of specific clients, beyond the fair use provisions granted by the U.S. Copyright Law is authorized by SPIE subject to payment of copying fees. The Transactional Reporting Service base fee for this volume is $\$ 18.00$ per article (or portion thereof), which should be paid directly to the Copyright Clearance Center (CCC), 222 Rosewood Drive, Danvers, MA 01923. Payment may also be made electronically through CCC Online at copyright.com. Other copying for republication, resale, advertising or promotion, or any form of systematic or multiple reproduction of any material in this book is prohibited except with permission in writing from the publisher. The CCC fee code is 0277$786 \times / 18 / \$ 18.00$.

Printed in the United States of America.

Publication of record for individual papers is online in the SPIE Digital Library.

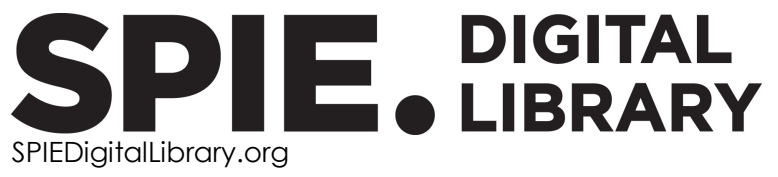

Paper Numbering: Proceedings of SPIE follow an e-First publication model. A unique citation identifier (CID) number is assigned to each article at the time of publication. Utilization of CIDs allows articles to be fully citable as soon as they are published online, and connects the same identifier to all online and print versions of the publication. SPIE uses a seven-digit CID article numbering system structured as follows:

- The first five digits correspond to the SPIE volume number.

- The last two digits indicate publication order within the volume using a Base 36 numbering system employing both numerals and letters. These two-number sets start with $00,01,02,03,04$, 05, 06, 07, 08, 09, OA, OB ... 0Z, followed by 10-1Z, 20-2Z, etc. The CID Number appears on each page of the manuscript. 


\title{
Contents
}

\author{
$\checkmark$ Authors \\ vii Conference Committee
}

NUMERICAL SIMULATION

1051504 Influence of microscopic many-body scattering on the performance of ultrashort pulsed and CW multi-wavelength VECSEL lasing (Invited Paper) [10515-1]

1051505 Passive mode-locking in a V-shaped cavity (Invited Paper) [10515-2]

NOVEL ARCHITECTURES/NEW WAVELENGTH

10515 OC Large pulse-energy VECSELs (Invited Paper) [10515-9]

10515 OE AlGaAs-based optically pumped semiconductor lasers [10515-11]

MODE-LOCKED I

$10515 \mathrm{OH}$ Structure and cavity geometry optimization for ultrashort and high power pulse generation from a VECSEL [10515-15]

FREQUENCY COMBS

10515 OK Carrier-envelope offset frequency stabilization of an ultrafast semiconductor laser [10515-18]

$10515 \mathrm{OM}$ Supercontinuum generation and beatnote detection using ultrafast VECSEL seed oscillators [10515-20]

\section{SINGLE FREQUENCY/INTRACAVITY CONVERSION}

$105150 \mathrm{~N}$ New developments in THz-time domain spectroscopy involving ML-VECSELs (Invited Paper) [10515-21]

1051500 Optically pumped semiconductor CW laser with 307nm output [10515-22]

$105150 Q \quad$ Vibration-tolerant narrow-linewidth semiconductor disk laser using novel frequencystabilisation schemes [10515-24] 
MODE-LOCKED II

10515 OS Commercial mode-locked vertical external cavity surface emitting lasers (Invited Paper) [10515-26]

10515 OT Degradation mechanism of SESAMs under intense ultrashort pulses in modelocked VECSELS [10515-27]

$105150 \mathrm{~V}$ Tantalum pentoxide waveguides and microresonators for VECSEL-based frequency combs [10515-29]

POSTER SESSION

$105150 X \quad$ Concept of the CW GaN-based VECSEL [10515-31] 


\section{Authors}

Numbers in the index correspond to the last two digits of the six-digit citation identifier (CID) article numbering system used in Proceedings of SPIE. The first four digits reflect the volume number. Base 36 numbering is employed for the last two digits and indicates the order of articles within the volume. Numbers start with 00, 01, 02, 03, 04, 05, 06, 07, 08, 09, 0A, 0B...0Z, followed by 10-1Z, 20-2Z, etc.

Addamane, Sadhvikas, $\mathrm{OH}, \mathrm{OT}$ Apostolopoulos, Vasilis, ON, OV Bai, Yanbo, OE

Baker, Caleb W., OH, OM

Balakrishnan, Ganesh, $\mathrm{OH}, \mathrm{OT}$

Bedford, Robert, OC

Bialkowski, Bartlomiej, OS

Brochard, Pierre, OK

Caprara, Andrea, 00

Chan, Hsiu-Ting, OT

Chen-Sverre, Theo, ON, OV

Chilla, Juan, OE

Churikov, Victor, 00

Diening, Andreas, $\mathrm{OE}$

Gibson, Ricky, OC

Gürel, Kutan, OK

Hader, Jorg, 04, OH

Hakobyan, Sargis, OK

Head, C. Robin, OS

Hempler, Nils, OS

Hua, Ping, OV

Hunter, Craig R., OQ

Jaurigue, Lina, 05

Jones, Brynmor E., $\mathrm{OQ}$

Jones, R. Jason, OM

Jornod, Nayara, OK

Keenlyside, Benjamin, ON

Keller, Ursula, OK

Kilen, Isak, 04, OH

Koch, Stephan W., 04, OH

Kuc, Maciej, OX

Laurain, Alexandre, $\mathrm{OH}, \mathrm{OM}$, ОT

Lin, Jipeng, OS

Lin, Yong, $\mathrm{OE}$

Lingnau, Benjamin, 05

Lubeigt, Walter, OS

Lüdge, Kathy, 05

Maker, Gareth T., OS

Malcolm, Graeme P. A., OS

McKnight, Loyd J., OQ

Meinecke, Stefan, 05

Moloney, Jerome $\mathrm{V}$., 04, OH, OM, OT

Myers, Joshua, OC

Ortega, Tiago, OS

Paboeuf, David, OS

Perez, Antje Ruiz, $\mathrm{OH}$

Piskorski, Łukasz, OX

Rockmore, Robert, $\mathrm{OH}, \mathrm{OM}$

Roth, Matthias, 00
Sarzala, Robert P., OX

Schilt, Stéphane, OK

Schlosser, Peter, $0 Q$

Scholz, Christian, OE

Shaw, E. A., OV

Shima, Darryl, OT

Sokół, Adam K., OX

Sørensen, Simon Toft, $0 Q$

Stolz, Wolfgang, $\mathrm{OH}$

Strain, Michael J., OQ

Südmeyer, Thomas, OK

Tropper, Anne C., ON, OV

Waldburger, Dominik, OK

Wasiak, Michał, OX

Weiss, Eli, OE

Wilkinson, J. S., OV

Wisdom, Jeffrey, OE, 00

Wittwer, Valentin J., OK

Woods, Jonathan R. C., ON, OV

Wu, Tsung-Han, $\mathrm{OM}$

XU, Zuntu, OE 
Proc. of SPIE Vol. $105151051501-6$

Downloaded From: https://www.spiedigitallibrary.org/conference-proceedings-of-spie on 25 Apr 2023 Terms of Use: https://www.spiedigitallibrary.org/terms-of-use 


\section{Conference Committee}

Symposium Chairs

Koji Sugioka, RIKEN (Japan)

Reinhart Poprawe, Fraunhofer-Institut für Lasertechnik (Germany)

Symposium Co-Chairs

Xianfan Xu, Purdue University (United States)

Beat Nevenschwander, Berner Fachhochschule Technik und Informatik (Switzerland)

Program Track Chairs

Kunihiko Washio, Paradigm Laser Research Ltd. (Japan)

John Ballato, Clemson University (United States)

\section{Conference Chair}

Juan L. Chilla, Coherent, Inc. (United States)

Conference Program Committee

Arnaud Garnache, Université Montpellier (France)

Mircea Guina, Tampere University of Technology (Finland)

Jennifer E. Hastie, University of Strathclyde (United Kingdom)

Michael Jetter, Universität Stuttgart (Germany)

Elyahou Kapon, Ecole Polytechnique Fédérale de Lausanne (Switzerland)

Ursula Keller, ETH Zurich (Switzerland)

Walter Lubeigt, M Squared Lasers Ltd. (United Kingdom)

Jerome V. Moloney, College of Optical Sciences, The University of Arizona (United States)

Wolfgang Stolz, NAsP III/V GmbH (Germany)

Anne C. Tropper, University of Southampton (United Kingdom)

Keith G. Wilcox, University of Dundee (United Kingdom)

Session Chairs

1 Numerical Simulation

Ursula Keller, ETH Zurich (Switzerland)

2 MECSEL

Juan L. Chilla, Coherent, Inc. (United States) 
3 Novel Architectures/New Wavelength

Jennifer Hastie, University of Strathclyde (United Kingdom)

4 Mode-locked I

Keith G. Wilcox, University of Dundee (United Kingdom)

5 Frequency Combs

Michael Jetter, Universität Stuttgart (Germany)

6 Single Frequency/Intracavity Conversion

Mircea Guina, Tampere University of Technology (Finland)

7 Mode-locked II

Anne C. Tropper, University of Southampton (United Kingdom) 